\title{
PENGARUH DEWAN PENGAWAS SYARIAH, INTELLECTUAL CAPITAL, DAN CORPORATE SOCIAL RESPONSIBILITY TERHADAP KINERJA BANK SYARIAH DI INDONESIA
}

\author{
Renny Zuliana*1, Aliamin $^{* 2}$ \\ ${ }^{1,2}$ Program Studi Akuntansi Fakultas Ekonomi dan Bisnis Universitas Syiah Kuala \\ e-mail: rennyzuliana@gmail.com ${ }^{* 1}$, aliamin@ unsyiah.ac.id ${ }^{{ }^{2}}$
}

\begin{abstract}
This study aimed to examine the effect of sharia supervisory board, intellectual capital, and corporate social responsibility toward performance of islamic bank in Indonesia. The type of research used in this study is quantitative, using secondary data. Data taken from company's financial statement and implementation report of GCG which audited of islamic bank in Indonesia during 2014-2016. In this research used purposive sampling method, 11 over 13 Islamic Banking can be used as samples. Analysis of data to test the hypothesis used multiple linear regression and are processed by SPSS 20th version program. The results of the study state that sharia supervisory board, IC, and CSR simultaneously influence the performance of Islamic banks which are proxied by ROA. Partially sharia supervisory board has a negative and significant effect on ROA, IC has a positive and significant effect on ROA. While the results of testing partially CSR does not affect ROA as a proxy for the performance of Islamic banks
\end{abstract}

Keywords: Sharia Supervisory Board, Intellectual Capital, Corporate Social Responsibility, Performance of Islamic Bank.

\section{Pendahuluan}

Sektor perbankan syariah merupakan instrumen penting yang memiliki pengaruh pada kemajuan ekonomi Islam itu sendiri. Pada dasarnya perbankan syariah adalah sistem perbankan yang dalam usahanya berdasarkan pada prinsip hukum syariah Islam yang mengacu pada Al-Quran dan Hadist.

Pendirian bank syariah memiliki tujuan untuk menerapkan prinsip-prinsip islam. Prinsip utama yang harus dimiliki perbankan syariah yaitu dalam setiap bentuk transaksi apapun tidak mengandung unsur riba, memperoleh keuntungan yang sesuai dengan kegiatan usaha yang dilakukannya, serta menyisihkan keuntungan untuk memberi zakat (Kholid dan Bachtiar, 2015). Karena prinsip perbankan syariah yang demikian, pendirian bank syariah ini sangat diminati oleh masyarakat. Menurut Fauziah dan Yudho (2013) minat masyarakat terhadap lembaga keuangan yang berdasarkan pada prinsip syariah semakin meningkat. Hal ini dibuktikan dengan pertumbuhan perbankan syariah di Indonesia berdasarkan data statistik dapat dilihat pada Tabel 1.1 di bawah ini.
Tabel 1.1

Perkembangan Jumlah Institusi Perbankan Syariah di Indonesia Periode 2012-2016

\begin{tabular}{|c|c|c|c|c|c|}
\hline \multirow[t]{2}{*}{ Indikator } & \multicolumn{5}{|c|}{ Tahun } \\
\hline & 2012 & 2013 & 2014 & 2015 & 2016 \\
\hline $\begin{array}{l}\text { Bank Umum } \\
\text { Syariah }\end{array}$ & 11 & 11 & 12 & 12 & 13 \\
\hline $\begin{array}{l}\text { Unit Usaha } \\
\text { Syariah }\end{array}$ & 24 & 23 & 22 & 22 & 21 \\
\hline $\begin{array}{l}\text { Bank } \\
\text { Pembiayaan } \\
\text { Rakyat } \\
\text { Syariah }\end{array}$ & 158 & 163 & 163 & 163 & 166 \\
\hline
\end{tabular}

Sumber: OJK, Statistik Perbankan Syariah (2016)

Berdasarkan data tersebut, menunjukkan bahwa jumlah Bank Umum Syariah (BUS) pada tahun 2012 sampai dengan 2013 masih berjumlah 11 bank, kemudian tahun 2014 bertambah menjadi 12 bank dan selanjutnya pada tahun 2016 juga bertambah menjadi 13 bank. Lain halnya dengan Unit Usaha Syariah (UUS), terjadi penurunan dari tahun 2012 hingga 2016 ini disebabkan adanya UUS yang menjadi BUS. Sama halnya dengan BUS, Bank Pembiayaan Rakyat Syariah (BPRS) turut mengalami peningkatan pada 
tahun 2016 yaitu 166 bank, dimana pada tahun 2012 hanya berjumlah 158 bank.

Pertumbuhan yang pesat, perusahaan salah satunya perbankan juga harus didukung dengan kinerja yang bagus, baik dari segi aspek keuangan dan non keuangan. Kinerja perbankan secara umum merupakan gambaran prestasi yang dicapai oleh bank dalam operasionalnya. Melalui kinerja dapat diketahui bagaimana gambaran kondisi keuangan bank pada suatu periode tertentu baik mencakup aspek penghimpun dana maupun penyaluran dananya.

Kinerja keuangan suatu bank dapat dinilai dari beberapa indikator, yang dijadikan dasar penilaian adalah laporan keuangan bank yang bersangkutan. Salah satu indikatornya adalah Return On Asset (ROA), rasio ini digunakan untuk mengukur sejauh mana kemampuan perusahaan menghasilkan laba yang diperoleh dari aset yang dananya sebagian besar berasal dari dana masyarakat. Faktor prediktor yang bisa meningkatkan kinerja, seperti dengan menerapkan Good Corporate Governance (GCG) dan pelaksanaan Corporate Social Responsibility (CSR). Syam dan Nadja (2012) menyatakan bahwa tanggung jawab keuangan yang dilihat dari ukuran moneter, akuntansi, maupun rasio-rasio tertentu, juga harus dilengkapi dengan kinerja non keuangan seperti penerapan Good Corporate Governance (GCG) dan pelaksanaan Corporate Social Responsibility (CSR) yang memadai.

Tata Kelola Perusahaan atau disebut Corporate Governance adalah rangkaian proses, kebiasaan, kebijakan, aturan, dan institusi yang memengaruhi pengarahan, pengelolaan, serta pengontrolan suatu perusahaan. GCG terhadap Bank Umum Syariah dan Unit Usaha Syariah yang telah diatur oleh PBI No. 11/33/PBI/2009 yang berlandaskan pada keterbukaan (transparency), akuntabilitas (accountability), pertanggungjawaban (responsibility), profesional (professional), dan kewajaran (fairness). Pelaksanaan GCG pada perbankan syariah dan konvensional mempunyai tujuan yang sama, tetapi yang membedakannya adalah di bank syariah harus memenuhi kepatuhan pada prinsip syariah (syariah compliance). Kepatuhan pada prinsip syariah ini diserahkan kepada Dewan Pengawas Syariah (DPS). Oleh karena itu, Dewan Pengawas Syariah (DPS) memiliki peran penting dalam bertugas sebagai pihak yang mengawasi dan memastikan bahwa dalam operasional bank syariah sesuai dengan prinsip syariah.

Menurut Muttakin dan Ullah (2012), semakin banyak anggota DPS maka akan mendorong kinerja yang lebih baik karena dewan lebih memiliki pengalaman, keahlian, kepakaran, dan memiliki jaringan profesional serta sosial yang lebih baik. Semakin banyak DPS maka pengawasan juga lebih baik sehingga tingkat kepatuhan syariah menjadi lebih baik. Adanya pengawasan yang baik dapat menurunkan masalah agensi yang dilakukan pihak manajemen bank syariah, dengan menurunnya masalah agensi maka kinerja akan lebih baik.

Perkembangan bank syariah yang cukup dinamis juga tidak terlepas dari kebijakan yang dilaksanakan Bank Indonesia pada tahun 2011, salah satunya adalah peningkatan kualitas human capital. Masa depan dan prospek bank syariah akan bergantung pada bagaimana kemampuan manajemen untuk mendayagunakan nilai yang tidak tampak dari aset tidak berwujud. Selain itu, peningkatan physical capital dan structural capital juga menjadi ukuran dan penilaian terhadap aset tidak berwujud tersebut, yang sering dikenal dengan intellectual capital.

Intellectual capital merupakan unsur yang penting bagi bank syariah dalam penciptaan nilai perusahaan. Fenomena intellectual capital di Indonesia sendiri mulai berkembang terutama sejak munculnya PSAK No. 19 tentang Aktiva tidak Berwujud. Menurut PSAK No. 19, aktiva tidak berwujud adalah aktiva non moneter yang dapat diidentifikasi dan tidak mempunyai wujud fisik serta dimiliki untuk digunakan dalam menghasilkan atau menyerahkan barang atau jasa, disewakan kepada pihak lainnya, atau untuk tujuan administratif (IAI, 2002).

Ditinjau dari segi ekonomi keberadaan bank syariah memang diharapkan untuk selalu terusmenerus berkembang dan mendapat keuntungan yang setinggi-tingginya. Namun di sisi lain, bank syariah tidak hanya dihadapkan pada tanggung jawab dalam perolehan keuntungan saja, melainkan bank syariah juga harus memperhatikan aspek sosial, yakni menjaga hubungan dengan masyarakat maupun lingkungan sekitarnya. Menurut Sriviana (2013) Corporate Social Responsibility (CSR) sebagai operasi bisnis yang berkomitmen tidak hanya untuk meningkatkan keuntungan bagi bank syariah secara finansial, 
melainkan juga untuk pembangunan sosial ekonomi kawasan secara holistik, melembaga, dan berkelanjutan. Pengertian CSR yang relatif lebih mudah dipahami dan dioperasionalkan adalah dengan mengembangkan konsep Tripple Bottom Lines (profit, planet, dan people) yang digagas oleh Elkington. Bagi investor, perusahaan yang melakukan aktivitas CSR berpotensi dalam menghasilkan laba yang lebih besar dibandingkan yang tidak, sehingga kedepannya perusahaan akan mampu meningkatkan kinerja keuangannya (Rosiliana et al., 2014).

Kinerja yang baik dapat mempengaruhi keberlangsungan bank syariah untuk maju dan kerjasama antara bank syariah yang satu dengan bank syariah yang lain, maka hal ini dapat menimbulkan tantangan bagi para akuntan untuk mengidentifikasi, mengukur, dan mengungkapkan nya dalam laporan keuangan. Berdasarkan laporan keuangan Bank Syariah pada tahun 2012-2016 yang terdaftar pada Bank Indonesia secara umum dapat dilihat mengenai rata-rata Return On Asset, Dewan Pengawas Syariah, Intellectual Capital, dan Corporate Social Responsibility pada Tabel 1.2 dibawah ini.

Tabel 1.2

\begin{tabular}{|c|c|c|c|c|c|}
\hline \multicolumn{6}{|c|}{$\begin{array}{c}\text { Rata-rata Perbandingan Return On Asset, Dewa } \\
\text { Pengawas Syariah, Intellectual Capital, dan } \\
\text { Corporate Social Responsibility }\end{array}$} \\
\hline Variabel & & & Tahun & & \\
\hline & 2012 & 2013 & 2014 & 2015 & 2016 \\
\hline ROA & $1,05 \%$ & $0,85 \%$ & $0,40 \%$ & $-1,32 \%$ & $\begin{array}{c}- \\
1.23 \%\end{array}$ \\
\hline DPS & 1,55 & 1,41 & 1, & 1,78 & 1,85 \\
\hline IC & 2,88 & 2,76 & 1,7 & 2,64 & 6,92 \\
\hline CSR & 5,06 & 5,89 & 9,58 & 12,77 & 8,60 \\
\hline
\end{tabular}

(Milyar)

Sumber: Data Laporan Tahunan yang Diolah (2017)

Berdasarkan tabel tersebut, secara rata-rata menunjukkan bahwa Return On Asset (ROA) mengalami penurunan dari tahun ke tahun. Dalam teori agensi, salah satu cara untuk menghindar dari kemungkinan timbulnya konflik agensi adalah dengan menyelenggarakan pengawasan. Adanya pengawasan yang baik dapat menurunkan masalah agensi yang dilakukan pihak manajemen bank syariah, dengan menurunnya masalah agensi maka kinerja akan lebih baik. Pada bank syariah, pengawasan dilakukan oleh DPS dengan memastikan bahwa dalam operasionalnya sesuai dengan prinsip syariah. Penilaian DPS yang digunakan oleh BUS sendiri adalah menggunakan parameter penilaian self assessment : Peringkat 1 nilai komposit $<1,5$ (predikat sangat baik), Peringkat 2 nilai komposit $<2,5$ (predikat baik), Peringkat 3 nilai komposit $<3,5$ (predikat cukup baik), Peringkat 4 nilai komposit $<4,5$ (predikat kurang baik), dan Peringkat 5 nilai komposit $\leq 5$ (predikat tidak baik). Namun, ratarata penilaian DPS berpredikat baik, sedangkan ROA terus memburuk atau mengalami penurunan secara berkala.

Pada Tabel yang sama, Intellectual Capital terjadi penurunan dari tahun 2012 ke tahun 2014, ROA juga mengalami penurunan. Pada saat terjadi peningkatan Intellectual Capital pada tahun 2015 terjadi penurunan pada ROA. Menurut teori yang dinyatakan oleh Steward (1997), Intellectual Capital mencerminkan sumber daya yang dimiliki perusahaan berupa pengetahuan untuk menghasilkan aset yang lebih tinggi. Modal kerja intelektual mencakup semua pengetahuan karyawan, organisasi, dan kemampuan mereka untuk menciptakan nilai tambah serta menyebabkan keunggulan kompetitif berkelanjutan. Jika perusahaan berhasil dalam mengelola Intellectual Capital, maka hal itu dapat meningkatkan kinerja perusahaan.

Jika dilihat dari Corporate Social Responsibility (CSR) mengalami peningkatan dari tahun $2012 \mathrm{ke}$ tahun 2015, berbeda dengan ROA yang mengalami penurunan dari tahun 2012 ke tahun 2015. Pada tahun 2016 CSR mengalami penurunan kembali, dan ROA juga mengalami penurunan. Hal ini tidak sejalan dengan teori yang menyatakan bahwa Corporate Social Responsibility dapat menjadi pertimbangan investor sebelum berinvestasi, karena didalamnya mengandung informasi sosial yang telah dilakukan perusahaan. Dengan pelaporan dan pengungkapan CSR, perusahaan akan dipandang sebagai perusahaan yang memiliki jiwa sosial tinggi, sehingga investor sebagai stakeholder akan lebih tertarik berinvestasi di perusahaan. Semakin banyak investor yang masuk tentu pendapatan atau income perusahaan akan semakin meningkat. Dilihat dari hasil pada Tabel 1.2 berbeda dengan teori yang diungkapkan, sehingga hal ini membuat peneliti ingin meneliti variabel-variabel tersebut lebih lanjut lagi.

Otoritas Jasa Keuangan (OJK) memandang perkembangan industri keuangan syariah sempat mengalami peningkatan yang baik, namun belakangan 
kinerjanya menurun. OJK mengatakan bahwa rasio profitabilitas dari Return On Asset (ROA) pada industri perbankan menurun tipis, karena bank-bank perlu menggelembungkan biaya pencadangan akibat meningkatnya rasio kredit bermasalah atau NonPerforming Loan (NPL). (Republika.co.id, 2017).

Semakin berkembangnya bank syariah berimplikasi pada semakin besarnya tantangan yang harus dihadapi bank syariah, di mana tantangan terbesar adalah untuk mempertahankan citra dan nama baik di mata nasabah agar tetap menjaga kepercayaan serta loyalitas nasabah kepada bank syariah. Sebagaimana yang diketahui bank syariah merupakan bank yang menjalankan kegiatan usahanya berdasarkan prinsip-prinsip syariah yang bersumber dari al-Qur'an dan Hadist yang diterapkan baik dilingkungan dalam maupun luar perusahaan (Najib dan Rini, 2016).

Penelitian ini dilakukan dengan mengacu pada penelitian-penelitian yang dilakukan oleh Asrori (2014), Nurhikmah et al (2018), Nizar dan Anwar (2015), juga Arifin dan Wardani (2016). Penelitian yang dilakukan oleh Asrori 2014 adalah Implementasi islamic corporate governance dan implikasinya terhadap kinerja bank syariah, menggunakan variabel independen kinerja islami dan konvensional serta dua variabel independen yaitu islamic corporate governance pelaksanaan tugas dan tanggungjawab Dewan Pengawas Syariah (DPS) dan islamic corporate governance kepatuhan syariah periode 2010 dan 2011. Nurhikmah et al (2018) melakukan penelitian pengaruh dewan pengawas syariah (DPS) dan intellectual capital (IC) terhadap pengungkapan corporate social responsibility (CSR) dengan kinerja keuangan sebagai variabel mediasi (studi empiris perbankan syariah di Indonesia).

Penelitian yang dilakukan oleh Nizar dan Anwar (2015) adalah pengaruh pembiayaan jual beli, pembiayaan bagi hasil dan intellectual capital terhadap kinerja bank syariah periode 2011-2014. Arifin dan Wardani (2016) juga melakukan penelitian mengenai islamic corporate social responsibility disclosure, reputasi, dan kinerja keuangan, studi pada bank syariah di Indonesia. Pengukuran ICSR nya menggunakan ISRI 38 item pengungkapan. Perbedaan penelitian ini dengan penelitian sebelumnya adalah menggunakan variabel dependen kinerja dan tiga variabel independen yang digunakan dewan pengawas syariah, intellectual capital, dan corporate social responsibility menggunakan indeks ISR 50 item dengan masa periode 2014-2016.

Berdasarkan uraian latar belakang masalah tersebut, maka penelitian ini dilakukan untuk mengetahui atau melihat seberapa berpengaruhnya DPS, IC, dan CSR terhadap Kinerjanya dalam proposal skripsi yang berjudul "Pengaruh Dewan Pengawas Syariah, Intellectual Capital, dan Corporate Social Responsibility terhadap Kinerja Bank Syariah di Indonesia".

\section{Kerangka Teoritis Dan Pengembangan Hipotesis Kerangka Teoritis \\ Bank Syariah}

Menurut Undang-undang Nomor 21 Tahun 2008 pasal 1 ayat 7 tentang Perbankan Syariah, bank syariah adalah bank yang menjalankan kegiatan usahanya berdasarkan prinsip syariah dan menurut jenisnya terdiri atas bank umum syariah dan bank pembiayaan rakyat syariah, sedangkan menurut Sudarsono (2012:29) bank syariah merupakan lembaga keuangan yang usaha pokoknya memberikan kredit atau pembiayaan, dan jasa-jasa lainnya dalam lalu lintas pembayaran serta pengedaran uang yang beroperasi disesuaikan dengan prinsip-prinsip syariah.

\section{Kinerja Bank Syariah}

Pengukuran kinerja keuangan dapat dinyatakan dalam bentuk rasio keuangan. Rasio profitabilitas merupakan rasio untuk mengukur kemampuan perusahaan dalam menghasilkan laba.

Selain itu, BI juga lebih mengutamakan profitabilitas suatu bank diukur dari aset yang dananya sebagian besar berasal dari dana masyarakat, sehingga ROA lebih mewakili (Dendawijaya, 2005 dalam Putrianingsih dan Yulianto, 2016).

Kinerja merupakan cerminan dari kemampuan perusahaan dalam mengelola dan mengalokasikan sumber dayanya dalam operasional perusahaan. Pengelolaan dan pengalokasian tersebut diwujudkan dengan adanya intellectual capital. Menurut Libyanti dan Wahidahwati (2016), dengan adanya konsep intellectual capital maka perusahaan akan mampu menghasilkan keunggulan yang kompetitif dan kinerja keuangan yang baik. Selain itu, penilaian kinerja suatu entitas bisnis maupun manajemen bisnis dewasa ini tidak hanya diukur dari aspek keuangan. Tanggung 
jawab keuangan yang ditampakkan dengan ukuran moneter, akuntansi maupun rasio-rasio tertentu juga harus dilengkapi dengan kinerja non-keuangan seperti penerapan good corporate governance dan pelaksanaan corporate social renponsibility (Syam dan Nadja, 2012).

\section{Dewan Pengawas Syariah}

Bank syariah dalam operasionalnya dijalankan sesuai dengan ketentuan perbankan yang berlaku dan juga sesuai dengan prinsip syariah. Untuk menjamin prinsip syariah telah diterapkan dalam aktivitas perbankan syariah terdapat salah satu pihak terafiliasi yaitu DPS yang memberikan jasanya kepada bank syariah.

DPS yaitu badan independen yang bertugas melakukan evaluasi (evaluating), pengarahan (directing), pemberian konsultasi (consulting), dan pengawasan (supervising) kegiatan bank syariah dalam rangka memastikan bahwa kegiatan usaha bank syariah tersebut mematuhi (compliance) terhadap prinsip syariah sebagaimana telah ditentukan oleh fatwa dan syariah islam (Rahmat, 2017). Sedangkan Dewan Syariah Nasional (DSN) Majelis Ulama Indonesia (MUI) menerangkan bahwa DPS adalah bagian dari lembaga keuangan syariah yang bersangkutan dengan penempatannya berdasarkan persetujuan Dewan Syariah Nasional (DSN). Tanggung jawab yang dipegang DPS ini bertujuan untuk membangun dan menjaga kepercayaan semua pemangku kepentingan bahwa seluruh transaksi, praktik, dan aktivitas dalam lingkup BUS berjalan sesuai dengan prinsip-prinsip syariah (Musibah dan Wan Sulaiman, 2014).

\section{Intellectual Capital}

Menurut Stewart (1997) dalam Ulum

(2013:189) mendefinisikan IC adalah:

"The sum of everything everybody in your company knows that gives you a competitive edge in the market place. It I intellectual material - knowledge, informasi, intellectual property, experience - that can be put to use to create wealth."

Artinya Intellectual Capital merupakan jumlah dari segala sesuatu tentang sumberdaya manusia yang ada di perusahaan yang dapat memberikan keunggulan kompetitif di pasar. Materi intelektual tersebut- pengetahuan, informasi, kekayaan intelektual, pengalaman- dapat dimanfaatkan untuk menciptakan kekayaan. Untuk mengukur intellectual capital belum ada suatu acuan standar yang baku. Salah satu peneliti yang telah mengungkapkan pengukuran intellectual capital adalah Pulic (1998),

\section{Corporate Social Responsibility}

Corporate Social Responsibility (CSR) merupakan proses pengkomunikasian dampak sosial dan lingkungan dari kegiatan ekonomi organisasi terhadap kelompok khusus yang berkepentingan dan terhadap masyarakat secara keseluruhan. Tanggung jawab sosial perusahaan itu sendiri dapat digambarkan sebagai ketersediaan informasi keuangan dan non keuangan berkaitan dengan interaksi organisasi dengan lingkungan fisik dan lingkungan sosialnya yang dapat dibuat dalam laporan tahunan perusahaan atau laporan sosial terpisah (Wardani, 2015).

Menurut John Elkington dalam buku yang berjudul "Cannibals with forks :The Triple Bottom line in 21st century Busines" pada tahun 1997 menyebutkan pemahaman CSR dengan 3P, yaitu profit, people, planet. Konsep ini memuat pengertian bahwa bisnis tidak hanya sekedar mencari keuntungan (profit) melainkan juga kesejahteraan orang (people), dan menjamin keberlangsungan hidup planet. Konsep CSR berkaitan erat dengan keberlangsungan atau sustainibility perusahaan. Penerapan corporate social responsibility dipercaya dapat meningkatkan kinerja keuangan perusahaan, di mana investor cenderung menanamkan modal pada perusahaan yang melakukan aktivitas CSR. Karena bagi investor, perusahaan yang melakukan aktivitas CSR berpotensi dalam menghasilkan laba yang lebih besar dibandingkan yang tidak, sehingga kedepannya perusahaan akan mampu meningkatkan kinerja keuangannya (Wardani, 2015).

\section{Pengembangan Hipotesis}

Pengaruh Dewan Pengawas Syariah, Intellectual Capital, dan Corporate Social Responsibility terhadap Kinerja Bank Syariah di Indonesia

Keberadaan Dewan Pengawas Syariah (DPS) di bank syariah merupakan salah satu unsur dari kepatuhan bank syariah. Keberadaan DPS adalah untuk memonitoring ketaatan bank syariah terhadap syariah Islam sehingga dapat diharapkan dapat 
menekan masalah agensi dan menjadikan kinerja bank syariah menjadi lebih baik.

Kholid dan Bachtiar (2015) menyatakan bahwa mekanisme DPS dapat meningkatkan kinerja bank syariah. DPS dalam melakukan pertemuan minimal 1 kali dalam sebulan, pertemuan yang dilakukan mencerminkan seberapa baik kinerja DPS dalam melaksanakan tugas dan tanggungjawabnya. Oleh karena itu, pelaksanaan tugas dan tanggungjawab DPS sangat penting agar dapat terlaksananya prinsip syariah dan menciptakan nilai bagi perbankan syariah.

Perkembangan bank syariah yang cukup dinamis tidak terlepas dari kebijakan yang dilaksanakan Bank Indonesia pada tahun 2011 yang salah satunya adalah peningkatan kualitas human capital. Masa depan dan prospek bank syariah akan bergantung pada bagaimana kemampuan manajemen untuk mendayagunakan nilai yang tidak tampak dari aset tidak berwujud. Penting untuk dilakukan pengukuran dan penilaian terhadap asset tidak berwujud tersebut, salah satunya dengan intellectual capital. Intellectual capital merupakan unsur yang penting bagi bank syariah dalam penciptaan nilai perusahaan dan memenangkan nilai. Di sisi lain, bank syariah tidak hanya dihadapkan pada tanggung jawab dalam perolehan keuntungan saja, melainkan bank syariah juga harus memperhatikan aspek sosial, yakni menjaga hubungan dengan masyarakat maupun lingkungan sekitarnya. Hal tersebut perlu dilakukan dalam menjaga eksistensi dan keberlanjutan usaha yang dijalani oleh bank syariah.

$\mathrm{H}_{1}$ : Dewan Pengawas Syariah, intellectual capital, dan corporate social responsibility berpengaruh secara simultan terhadap kinerja bank syariah di Indonesia.

\section{Pengaruh Dewan Pengawas Syariah terhadap Kinerja Bank Syariah di Indonesia}

Dalam teori agensi, salah satu cara untuk menghindar dari kemungkinan timbulnya konflik agensi adalah dengan menyelenggarakan pengawasan. Dewan Pengawas Syariah (DPS) memiliki peran penting dalam bertugas sebagai pihak yang mengawasi dan memastikan bahwa dalam operasional bank syariah sesuai dengan prinsip syariah.

Menurut Muttakin dan Ullah (2012), semakin banyak anggota DPS maka akan mendorong kinerja yang lebih baik karena dewan lebih memiliki pengalaman, keahlian, kepakaran, dan memiliki jaringan profesional serta sosial yang lebih baik. Semakin banyak DPS maka pengawasan juga lebih baik sehingga tingkat kepatuhan syariah menjadi lebih baik. Adanya pengawasan yang baik dapat menurunkan masalah agensi yang dilakukan pihak manajemen bank syariah, dengan menurunnya masalah agensi maka kinerja akan lebih baik.

Hal ini sesuai dengan penelitian yang dilakukan oleh Musibah dan Wan (2014) yang menyatakan bahwa DPS berpengaruh terhadap kinerja keuangan bank syariah. Mollah dan Zaman (2015) juga menyatakan bahwa ukuran DPS berpengaruh positif terhadap kinerja keuangan bank syariah. Hal tersebut menunjukkan bahwa perusahaan yang melakukan pengawasan yang baik akan menurunkan agensi dan memperoleh manfaat yang lebih besar terhadap lingkungan ekonomi.

$\mathrm{H}_{2}$ : Dewan Pengawas Syariah berpengaruh secara parsial terhadap kinerja bank syariah di Indonesia.

\section{Pengaruh Intellectual Capital terhadap Kinerja Bank Syariah di Indonesia}

Intellectual capital adalah sumber daya yang dimiliki oleh perusahaan, perusahaan haruslah menyadari intellectual capital adalah modal yang berharga. Hal ini berarti IC sangat berperan penting dalam peningkatan nilai perusahaan maupun kinerja keuangan.

Mayangtari dan Wahidahwati (2016), dalam penelitiannya telah membuktikan bahwa intellectual capital dengan menggunakan $\mathrm{VAIC}^{\mathrm{TM}}$ yang diformulasikan oleh Pulic (1998) mempunyai pengaruh positif terhadap kinerja keuangan perbankan syariah yang diproksikan dengan ROA. Oleh karena itu, semakin baik penggunaan intellectual capital sebuah perusahaan akan semakin meningkatkan competitive advantages yang dapat berkontribusi terhadap peningkatan kinerja keuangan perusahaan (Chen, Cheng, Hwang, 2005).

$\mathrm{H}_{3}$ : Intellectual capital berpengaruh secara parsial terhadap kinerja bank syariah di Indonesia.

Pengaruh Corporate Social Responsibility terhadap
Kinerja Bank Syariah di Indonesia
Corporate Social Responsibility (CSR) pada umumnya menyatakan bahwa tanggung jawab 
perusahaan tidak hanya terhadap pemilik atau pemegang saham saja, melainkan juga terhadap para stakeholder yang terkait atau terkena dampak dari keberadaan suatu perusahaan. Hal ini sesuai dengan teori stakeholder yang menyatakan bahwa perusahaan bukanlah entitas yang hanya beroperasi untuk kepentingannya sendiri namun harus memberi manfaat bagi stakeholdernya (Sriviana, 2013).

Shoukat dan Nadeem (2014) menyimpulkan bahwa lembaga keuangan yang menerapkan CSR lebih banyak dalam operasi mereka, maka akan memiliki kinerja keuangan perusahaan yang lebih baik dibandingkan perusahaan yang lebih sedikit menerapkannya. Hal ini juga sesuai dengan hasil penelitian Arifin dan Wardani (2016) yang menunjukkan bahwa CSR berpengaruh positif terhadap kinerja keuangan perusahaan.

$\mathrm{H}_{4}$ : Corporate Social Responsibility berpengaruh secara parsial terhadap kinerja bank syariah di Indonesia

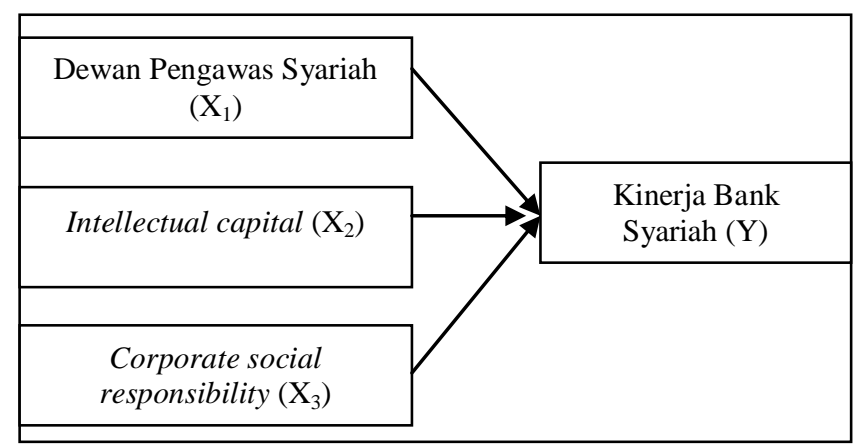

\section{Gambar.1 Kerangka Pemikiran}

\section{Metode Penelitian}

\section{Desain Penelitian}

Desain penelitian adalah bagan (blueprint) untuk pengumpulan, pengukuran, dan analisis data berdasarkan pada permasalahan studi penelitian (Sekaran dan Bougie, 2016:95). Terdapat enam aspek dasar desain penelitian yaitu tujuan studi, jenis investigasi, tingkat intervensi penelitian, situasi studi, unit analisis, dan horizon waktu penelitian (Sekaran dan Bougie, 2016:95).

1) Tujuan penelitian

Tujuan penelitian ini adalah untuk menguji hipotesis yang telah dirumuskan berdasarkan teoriteori dan penelitian terdahulu. Hipotesis yang dirumuskan yaitu untuk menguji pengaruh variabel independen terhadap variabel dependen.

2) Jenis Investigasi

Jenis investigasi dari penelitian ini bersifat studi kausalitas, di mana peneliti ingin menjelaskan pengaruh antar variabel yang diteliti, yaitu dewan pengawas syariah, intelectual capital, dan corporate social responsibility sebagai variabel independen dan kinerja bank syariah di Indonesia sebagai variabel dependen.

3) Intervensi Peneliti

Peneliti memiliki intervensi minimal terhadap variabel yang diteliti, karena peneliti hanya mengambil laporan GCG dan laporan keuangan tahunan perusahaan tanpa mempengaruhinya.

4) Lingkungan Studi

Lingkungan studi dalam penelitian ini adalah tidak diatur. Peneliti ingin menganalisis pengaruh dewan pengawas syariah, intelectual capital, dan corporate social responsibility terhadap kinerja bank syariah di Indonesia.

5) Unit Analisis

Unit analisis dalam penelitian ini adalah perbankan syariah yaitu seluruh bank umum syariah yang ada di Indonesia periode 2014-2016.

6) Horizon Waktu

Dalam penelitian ini horizon waktu yang digunakan adalah perpaduan cross sectional dan time series atau dikenal dengan data pooling (pooled data), yaitu tipe studi satu tahap yang datanya berupa sekelompok subjek dalam beberapa periode waktu.

\section{Populasi dan Sampel Penelitian}

Dalam penelitian ini populasi yang digunakan adalah seluruh BUS yang beroperasi di Indonesia pada tahun 2014-2016. Sampel penelitian ini menggunakan metode purposive sampling dengan kriteria sebagai berikut: (1) Terdaftar di Bank Indonesia. Pada kriteria ini, semua Bank Umum Syariah (BUS) yang dimaksud masih memenuhi syarat. (2) BUS yang mempublikasikan laporan pelaksanaan Good Corporate Governance dan laporan keuangan atau annual report-nya secara berkala mulai dari tahun 2014-2016 dan dapat diakses melalui website-nya masing-masing. (3) BUS yang memiliki data lengkap yang berkaitan dengan variabel yang digunakan. 
Berdasarkan kriteria-kriteria yang telah ditentukan, jumlah sampel yang digunakan penelitian ini dapat dilihat pada Tabel 3.2.

Tabel 3.2

Kriteria Objek Penelitian

\begin{tabular}{|l|c|}
\hline \multicolumn{1}{|c|}{ Kriteria } & BUS \\
\hline Terdaftar di BI & 13 \\
\hline $\begin{array}{l}\text { BUS yang tidak mempublikasikan } \\
\text { laporan Good Corporate Governance dan } \\
\text { laporan keuangan secara berkala mulai } \\
\text { dari tahun 2014-2016 dan tidak } \\
\text { mempunyai data lengkap }\end{array}$ & $(2)$ \\
\hline Jumlah Objek & 11 \\
\hline Total objek selama 3 tahun observasi & $\mathbf{3 3}$ \\
\hline
\end{tabular}

Sumber: Data diolah 2017

\section{Sumber dan Teknik Pengumpulan Data}

Sumber data dalam penelitian ini bersumber melalui media perantara dimana data-data penelitian diperoleh secara tidak langsung dan telah tersedia sehingga tidak perlu dikumpulkan oleh peneliti. Sumber data tersebut disebut juga dengan sumber data sekunder. Data sekunder yang digunakan dalam penelitian ini adalah laporan GCG dan laporan keuangan tahunan perbankan syariah dari tahun 2014-2016. Teknik pengumpulan data dalam penelitian ini dilakukan dengan teknik dokumentasi dengan cara mengakses dan mengunduh data berupa laporan GCG dan laporan keuangan tahunan Bank Syariah periode 2014-2016 pada website masingmasing.

\section{Operasionalisasi Variabel}

\section{Variabel Dependen (Y)}

Variabel dependen dalam penelitian ini adalah kinerja keuangan perbankan yang diproksikan dalam Return on Asset (ROA). ROA merupakan ukuran kemampuan perusahaan didalam menghasilkan keuntungan (return) bagi perusahaan dengan memanfaatkan aktiva yang dimilikinya. Semakin besar ROA menunjukkan kinerja yang semakin baik. ROA secara sistematis dirumuskan sebagai berikut (Brigham dan Houston, 2010:148):

$$
\text { ROA }=\frac{\text { Laba Bersih }}{\text { Total Aset }} \times 100 \%
$$

\section{Variabel Independen (X) \\ Dewan Pengawas Syariah}

Dewan Pengawas Syariah (DPS) adalah bagian dari lembaga keuangan syariah yang penempatannya atas persetujuan DSN-MUI (Dewan Syariah Nasional Majelis Ulama Indonesia). DPS dalam penelitian ini, diukur berdasarkan nilai komposit Self Assessment yang terdapat dalam laporan pelaksanaan GCG yang dilakukan BUS. Nilai komposit Sefl Assessment tersebut didapatkan dari laporan pelaksanaan GCG bagian hasil nilai komposit Self Assessment pada indikator pelaksanaan tugas dan tanggung jawab DPS. Skala yang digunakan dalam penelitian ini adalah skala rasio.

\section{Intellectual Capital}

Intellectual capital (IC) di diukur dengan model Pulic (1998) yaitu Islamic Banking Value Added Intellectual Coefficient (iB-VAIC ${ }^{\mathrm{TM}}$ ) yang diukur berdasarkan value added yang diciptakan oleh komponen intellectual capital yang terdiri dari iBValue Added Capital Employed (iB-VACA = VA/CE), iB-Value Added Human Capital (iB-VAHU = VA/HC), dan iB-Structural Capital Value Added (iBSTVA $=$ SC/VA) yang dimodifikasikan oleh Ulum (2009:15).

Rasio tersebut merupakan kalkulasi kemampuan intelektual sebuah perusahaan. Formulasi ini merupakan jumlah koefisien yang disebutkan sebelumnya. Hasilnya yaitu:

$i B-V A I C{ }^{T M}=i B-V A C A+i B-V A H U+i B-S T V A$

\section{Corporate Social Responsibility}

Dalam penelitian ini menggunakan Corporate Social Responsibility (CSR) dalam perspektif Islam. Pengungkapan CSR dalam perspektif islam menggunakan indeks ISR (Islamic Social Reporting), pengukurannya dapat diperoleh dari annual report masing-masing perusahaan tiap tahunnya.

Pokok-pokok pengungkapan sosial yang digunakan dalam penelitian ini merujuk pada penelitian Fauziah (2013) terdiri dari enam indikator pengungkapan, yaitu: tema investasi dan keuangan, tema produk dan jasa, tema tenaga kerja, tema sosial, tema lingkungan, dan tema tata kelola organisasi yang dikembangkan menjadi 50 item pernyataan. Skor tersebut diperoleh dengan menggunakan metode 
content analysis. Adapun rumus perhitungan CSR adalah sebagai berikut:

$$
\mathrm{CSR}=\frac{\sum \mathrm{xi}}{n} \times 100 \%
$$

Keterangan:

CSR : Corporate Social Responsibility

$\sum \mathrm{x}_{\mathrm{i}} \quad$ :Total item yang diungkap $(1=$ jika item diungkapkan; $0=$ jika item $\mathrm{i}$ tidak diungkapkan)

n : Jumlah item pengungkapan

Dari formula di atas, dapat dipahami bahwa skor CSR yang diperoleh berada pada kisaran 0\% hingga $100 \%$. Semakin tinggi skor CSR berarti semakin transparan BUS dalam mengungkap kegiatan tanggungjawab sosialnya, dan sebaliknya. Skala yang digunakan dalam penelitian ini adalah skala rasio.

\section{Hasil dan Pembahasan}

\section{Deskripsi Objek Penelitian}

Penelitian ini bertujuan menguji pengaruh dewan pengawas syariah, intellectual capital, dan corporate social responsibility terhadap kinerja bank syariah di Indonesia periode 2014-2016. Sumber data yang digunakan dalam penelitian ini adalah data sekunder, berupa laporan keuangan (annual report) dari 13 perusahaan perbankan syariah yang menjadi observasi (11 perbankan syariah untuk 3 tahun pengamatan) yang terpilih berdasarkan kriteria populasi sasaran yang telah ditentukan sebelumnya.

Analisis data dilakukan dengan menggunakan metode regresi linear berganda (multiple linear regression) dan pengujian hipotesis sesuai dengan rancangan pengujian hipotesis, pengolahan data menggunakan program SPSS versi 20. Langkah pertama yang dilakukan adalah dengan melakukan uji asumsi klasik untuk membuktikan bahwa data telah bebas dari uji asumsi klasik, kemudian dilanjutkan dengan melakukan pengujian hipotesis.

\section{Hasil Pengujian Asumsi Klasik} Uji Normalitas

Uji normalitas bertujuan untuk menguji apakah data yang dianalisis berdistribusi normal atau tidak (Ghozali, 2013: 160). Dalam penelitian ini menggunakan uji statistik Kolmogrov-Smirnov Test untuk menguji distribusi data. Hasil pengujian normalitas dapat dilihat pada Tabel 4.1.

Tabel 4.1

Hasil Uji Normalitas

One-Sample Kolmogorov-Smirnov Test

\begin{tabular}{|c|c|c|c|c|c|}
\hline & & ROA & DPS & IC & CSR \\
\hline $\mathrm{N}$ & & 33 & 33 & 33 & 33 \\
\hline Normal & Mean & -.7162 & .1791 & 3.7775 & .6673 \\
\hline Parameters ${ }^{\mathrm{a}}$ & $\begin{array}{l}\text { Std. } \\
\text { Deviatio } \\
\mathrm{n}\end{array}$ & $\begin{array}{r}3.8302 \\
5\end{array}$ & $\begin{array}{r}.0634 \\
6\end{array}$ & $\begin{array}{r}6.6913 \\
5\end{array}$ & 08829 \\
\hline Most & Absolute & .396 & .189 & .329 & .106 \\
\hline Extreme & Positive & .253 & .189 & .319 & .106 \\
\hline Differences & Negative & -.396 & -.175 & -.329 & -.098 \\
\hline $\begin{array}{l}\text { Kolmogorov- } \\
\text { Z }\end{array}$ & -Smirnov & 2.273 & 1.086 & 1.891 & .610 \\
\hline Asymp. Sig. ( & (2-tailed) & .000 & .189 & .002 & .851 \\
\hline
\end{tabular}

a. Test distribution is Normal.

b. Calculated from data.

Sumber: Output SPSS (2018)

Pada Tabel 4.1 dapat dilihat bahwa nilai Asymp. Sig. (2-tailed) untuk variabel Return On Asset (ROA) (Y) sebesar 0.000 lebih kecil dari 0.05 , hal ini menunjukkan bahwa data tidak berdistribusi normal. Variabel Dewan Pengawas Syariah (DPS) $\left(\mathrm{X}_{1}\right)$ nilai Asymp. Sig. (2-tailed) sebesar 0.189 lebih besar dari 0.05 , hal ini berarti menunjukkan datanya berdistribusi normal. Variabel Intellectual Capital (IC) $\left(\mathrm{X}_{2}\right)$ nilai Asymp. Sig. (2-tailed) sebesar 0.002 lebih kecil dari 0.05 , yang berarti bahwa datanya tidak berdistribusi normal. Variabel selanjutnya Corporate Social Responsibility (CSR) nilai Asymp. Sig. (2-tailed) sebesar 0.851 lebih besar dari 0.05 berarti dapat disimpulkan bahwa data terdistribusi secara normal.

Dari hasil uji statistik Kolmogrov-Smirnov Test ada sebagian data tidak terdistribusi secara normal, maka untuk mengatasi hal tersebut menurut Ghozali (2013:36) untuk menormalkan data dilakukan dengan cara mengubah data kedalam Lg10 (Logaritma 10), sehingga data yang dihasilkan terdistribusi secara normal. Hasil uji normalitas yang sudah diubah dalam bentuk Lg10 dapat dilihat pada Tabel 4.2. 
Tabel 4.2

Hasil Uji Normalitas dengan Data dalam Bentuk

Logaritma 10

One-Sample Kolmogorov-Smirnov Test

\begin{tabular}{|ll|r|r|r|r|}
\hline & & $\begin{array}{c}\text { Lg10_ } \\
\text { ROA }\end{array}$ & $\begin{array}{c}\text { Lg10_ } \\
\text { DPS }\end{array}$ & $\begin{array}{c}\text { Lg10 } \\
\text { IC }\end{array}$ & $\begin{array}{c}\text { Lg10_ } \\
\text { CSR }\end{array}$ \\
\hline $\mathrm{N}$ & & 27 & 33 & 32 & 33 \\
Normal & Mean & -.4277 & -.7742 & .4284 & -.1795 \\
Parameters & Std. & .42968 & .15846 & .3060 & .05843 \\
a,b & Deviation & 8 & \\
Most & Absolute & .132 & .228 & .196 & .101 \\
Extreme & Positive & .055 & .165 & .196 & .082 \\
Differences & Negative & -.132 & -.228 & -.170 & -.101 \\
Kolmogorov-Smirnov & .684 & 1.310 & 1.111 & .578 \\
Z & & .738 & .065 & .169 & .891 \\
Asymp. Sig. (2-tailed) & .72 &
\end{tabular}

a. Test distribution is Normal.

b. Calculated from data.

Sumber: Output SPSS (2018)

Hasil uji normalitas dengan data dalam bentuk logaritma 10 pada tabel 4.2 menunjukkan bahwa nilai Asymp. Sig. (2-tailed) semua variabel lebih besar dari 0.05, variabel Return On Asset (ROA) 0.738, Dewan Pengawas Syariah (DPS) 0.065, Intellectual Capital (IC) 0.169, dan Corporate Social Responsibility (CSR) 0.891. Hal ini berarti menunjukkan semua data berdistribusi normal.

\section{Uji Heteroskesdastisitas}

Uji Heteroskedastisitas bertujuan untuk menguji apakah dalam sebuah model regresi terjadi ketidaksamaan varian residual dari satu pengamatan ke pengamatan yang lain (Ghozali, 2013:139). Salah satu cara untuk mendeteksi ada tidaknya heteroskedastisitas dapat dilihat dengan menggunakan grafik scatterplot, dengan melihat ada atau tidaknya pembentukan pola tertentu pada grafik tersebut. Hasil pengujian heteroskedastisitas yang datanya sudah diubah dalam bentuk logaritma 10 dapat dilihat pada Gambar 4.3.

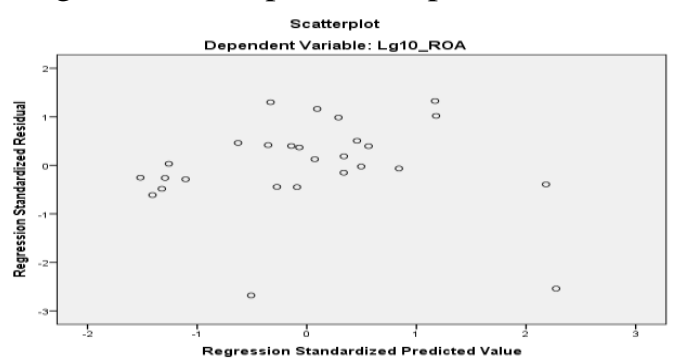
Gambar 4.3. Hasil Uji Heterokedastisitas
Logaritma 10 (Output SPSS, 2018)
Berdasarkan Gambar 4.3 yang datanya sudah diubah dalam bentuk logaritma 10 menunjukkan bahwa titik-titik menyebar dan tidak membentuk suatu pola yang jelas. Dilihat pada gambar scatterplot, titik menyebar dibawah titik nol dan diatas titik nol. Hal ini menunjukkan bahwa dalam model regresi tidak terjadi heteroskedastisitas.

\section{Uji Multikolonieritas}

Uji multikolonieritas bertujuan untuk melihat korelasi dua atau lebih variabel independen dalam sebuah model regresi berganda (Sekaran \& Bogie, 2013:319). Model regresi yang baik adalah yang tidak terdapat korelasi antara variabel independen. Untuk melihat ada atau tidaknya multikolonieritas di dalam regresi maka dapat dilihat dari nilai Tolerance dan nilai Variance Inflation Factor (VIF). Nilai batas yang digunakan untuk menunjukkan multikolonoeritas adalah jika nilai tolerance $>0,10$ dan $\mathrm{VIF}<10$, maka dapat disimpulkan data bebas dari multikolonieritas dan sebaliknya. Hasil pengujian multikolonieritas dapat dilihat pada Tabel 4.4 yang datanya sudah diubah dalam bentuk logaritma 10 .

\section{Tabel 4.4}

Hasil Uji Multikolonieritas dengan Data dalam Bentuk Logaritma 10

\begin{tabular}{|l|c|c|}
\hline \multicolumn{1}{|c|}{ Variabel } & Tolerance & VIF \\
\hline DPS & 0.903 & 1.108 \\
\hline IC & 0.953 & 1.049 \\
\hline CSR & 0.890 & 1.123 \\
\hline
\end{tabular}

Sumber: Output SPSS (2018)

Berdasarkan Tabel 4.4 yang datanya sudah diubah dalam bentuk logaritma 10, dapat dilihat bahwa variabel independen memiliki nilai tolerance yang lebih besar dari 0.10 dan nilai VIF yang lebih kecil dari 10 sehingga dapat disimpulkan bahwa tidak terdapat multikolonieritas antara variabel independen dalam model regresi.

\section{Uji Autokorelasi}

Uji Autokorelasi bertujuan untuk menguji apakah ada korelasi antara anggota serangkaian data observasi yang diuraikan menurut waktu (times series) atau ruang (crossection) (Suliyanto, 2011). Model regresi yang baik adalah model regresi yang bebas dari autokorelasi (Ghozali, 2013:110). Untuk menguji 
autokorelasi dalam penelitian ini menggunakan uji Durbin Watson (Durbin-Watson test). Hasil pengujian autokorelasi yang baru dapat dilihat pada Tabel 4.5.

\section{Tabel 4.5}

Hasil Uji Autokorelasi dengan Data dalam Bentuk Logaritma 10

Model Summary ${ }^{b}$

\begin{tabular}{|l|r|r|r|r|r|}
\hline Model & R & R Square & $\begin{array}{l}\text { Adjusted } \\
\text { R Square }\end{array}$ & $\begin{array}{r}\text { Std. Error of } \\
\text { the Estimate }\end{array}$ & $\begin{array}{c}\text { Durbin- } \\
\text { Watson }\end{array}$ \\
\hline 1 & $.662^{\mathrm{a}}$ & .438 & .365 & .34245 & 1.722 \\
\hline
\end{tabular}
a. Predictors: (Constant), Lg10_CSR, Lg10_IC, Lg10_DPS
b. Dependent Variable: Lg10_ROA

Sumber: Output SPSS (2018)

Hasil pengujian autokorelasi dengan mentransformasikan data dalam bentuk logaritma 10 pada Tabel 4.5 menunjukkan bahwa pada nilai DW untuk 33 observasi dan 3 variabel yang menjelaskan nilai $\mathrm{dU}=1.651$ dan $4-\mathrm{dU}=2.349$ dengan nilai $\mathrm{DW}=$ $1.722(1.651<1.722<2.349)$, ini berarti bahwa model regresi tidak terjadi masalah autokorelasi.

\section{Pengujian Hipotesis}

\section{Metode Regresi Linear Berganda}

Penelitian ini merupakan penelitian dengan pengujian hipotesis yang menggunakan metode analisis linear berganda (multiple linear regression), untuk mengetahui pengaruh variabel independen yaitu Dewan Pengawas Syariah, Intellectual Capital, dan Corporate Social Responsibility terhadap variabel dependen Kinerja Perbankan Syariah di Indonesia yang diproksikan dengan Return On Asset (ROA). Berdasarkan uji hipotesis yang telah dilakukan dengan menggunakan bantuan program SPSS (Statistical Package For Social Science) versi 20, pengaruh masing-masing variabel independen terhadap variabel dependen menunjukkan hasil sebagai berikut:

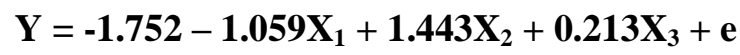

Rincian hasil regresi dapat dilihat pada Tabel 4.6
Tabel 4.6

Pengaruh Variabel Independen terhadap Variabel Dependen

\begin{tabular}{|l|c|c|}
\hline \multicolumn{4}{|c|}{ Persamaan Regresi Linear Berganda } \\
\hline \multicolumn{1}{|c|}{$\mathbf{1 . 7 5 2}_{\mathbf{1 . 0 5 9}} \mathbf{1}+\mathbf{1 . 4 4 3}_{\mathbf{2}}+\mathbf{0 . 2 1 3}_{\mathbf{3}}+\mathbf{e}$} \\
\hline Nama Variabel & $\mathrm{B}$ & $\begin{array}{l}\text { Standar } \\
\text { Error }\end{array}$ \\
\hline Konstanta $(\alpha)$ & -1.752 & 0.415 \\
\hline Dewan Pengawas Syariah (DPS) & -1.059 & 0.472 \\
\hline Intellectual Capital (IC) & 1.443 & 0.387 \\
\hline $\begin{array}{l}\text { Corporate Social Responsibility } \\
\text { (CSR) }\end{array}$ & 0.213 & 1.359 \\
\hline $\begin{array}{l}\text { Koefisien Korelasi }(\mathrm{R})=0.662^{\mathrm{a}} \\
\text { Koefisien Determinasi }\left(\mathrm{R}^{2}\right)=0.438\end{array}$ \\
\hline
\end{tabular}

Sumber: Data diolah (2018)

Berdasarkan persamaan regresi linear berganda dapat diketahui bahwa:

1. Konstanta (a) sebesar -1.752 , artinya jika DPS (X1), IC (X2), dan CSR (X3) dianggap konstan maka rata-rata nilai ROA akan berkurang sebesar 1.752.

2. Koefisien regresi DPS $\left(\mathrm{X}_{1}\right)$, sebesar -1.059 , nilai koefisien regresi yang negatif menunjukkan tidak adanya hubungan yang searah antara variabel DPS dengan ROA. Hal ini menunjukkan bahwa jika variabel DPS naik satu satuan maka akan menurunkan nilai ROA sebesar -1.059

$(-105,9 \%)$ dengan asumsi variabel bebas lainnya dianggap konstan.

3. Koefisien regresi IC $\left(\mathrm{X}_{2}\right)$, sebesar 1.443 , nilai koefisien regresi yang positif menunjukkan adanya hubungan yang searah antara variabel IC dengan ROA. Hal ini menunjukkan bahwa jika variabel IC naik satu satuan maka akan menaikkan nilai ROA sebesar $1.443(144,3 \%)$ dengan asumsi variabel bebas lainnya dianggap konstan.

4. Koefisien regresi CSR $\left(\mathrm{X}_{3}\right)$, sebesar 0.213, nilai koefisien regresi yang positif menunjukkan adanya hubungan yang searah antara variabel CSR dengan ROA. Hal ini menunjukkan bahwa jika variabel CSR naik satu satuan maka akan menaikkan nilai ROA sebesar 0.213 (21,3\%) dengan asumsi variabel bebas lainnya dianggap konstan.

\section{Pengujian Secara Simultan (Uji F)}

Untuk pengujian hipotesis pertama $\left(\mathrm{H}_{1}\right)$ dilakukan pengujian uji $F$. Uji statistik $F$ pada dasarnya menunjukkan apakah semua variabel independen yang dimasukkan dalam model 
mempunyai pengaruh secara bersama-sama terhadap variabel dependen (Ghozali, 2013:98). Hasil pengujian statistik F dapat dilihat pada Tabel 4.7.

Tabel 4.7

Hasil Uji Statistik F ANOVA $^{\mathrm{a}}$

\begin{tabular}{|rl|r|r|r|r|r|}
\hline \multicolumn{1}{|l|}{ Model } & $\begin{array}{r}\text { Sum of } \\
\text { Squares }\end{array}$ & $\mathrm{df}$ & $\begin{array}{c}\text { Mean } \\
\text { Square }\end{array}$ & $\mathrm{F}$ & Sig. \\
\hline \multirow{2}{*}{$1 \quad$ Regression } & 2.103 & 3 & .701 & 5.978 & $.004^{\mathrm{b}}$ \\
& Residual & 2.697 & 23 & .117 & & \\
& Total & 4.800 & 26 & & & \\
\hline
\end{tabular}

b. Predictors: (Constant), Lg10_CSR, Lg10_IC, Lg10_DPS

a. Dependent Variable: Lg10_ROA

Sumber: Output SPSS (2018)

Berdasarkan tabel 4.7 hasil uji $\mathrm{F}$ diatas menunjukkan bahwa nilai $\mathrm{F}$ sebesar 5.978 dan Signifikansi sebesar $0.004^{\mathrm{b}}$ lebih kecil dari nilai signifikansi $<0.05$, maka dapat disimpulkan hipotesis pertama $\left(\mathrm{H}_{1}\right)$ yang menyatakan bahwa dewan pengawas syariah, intellectual capital, dan corporate social responsibility berpengaruh secara simultan terhadap kinerja bank syariah di Indonesia dapat diterima.

\section{Pengujian Secara Parsial (Uji t)}

Uji t pada dasarnya menunjukkan seberapa jauh pengaruh satu variabel independen secara individual dalam menerangkan variabel dependen (Ghozali, 2013, 98). Hasil pengujian statistik t dapat dilihat pada Tabel 4.8.

\section{Tabel 4.8}

\section{Hasil Uji Statistik t \\ Coefficients $^{\mathrm{a}}$}

\begin{tabular}{|l|r|r|r|r|r|}
\hline Model & \multicolumn{2}{|c|}{$\begin{array}{c}\text { Unstandardized } \\
\text { Coefficients }\end{array}$} & $\begin{array}{r}\text { Standardize } \\
\mathrm{d} \\
\text { Coefficient } \\
\mathrm{s}\end{array}$ & Sig. \\
& \multicolumn{1}{|c|}{$\mathrm{B}$} & \multicolumn{1}{|c|}{ Std. } & \multicolumn{1}{c|}{ Beta } & & \\
& & Error & & & \\
\hline (Constant) & -1.752 & .415 & & -4.223 & .000 \\
1 Lg10_DPS & -1.059 & .472 & -.369 & -2.243 & .035 \\
Lg10_IC & 1.443 & .387 & .597 & 3.729 & .001 \\
Lg10_CSR & .213 & 1.359 & .026 & .157 & .877 \\
\hline
\end{tabular}

a. Dependent Variable: Lg10_ROA

Sumber: Output SPSS (2018)
Berdasarkan tabel 4.8 hasil uji $\mathrm{t}$ diatas menunjukkan bahwa:

a) Hasil pengujian pada variabel dewan pengawas syariah didapatkan nilai t hitung sebesar -2.243. Nilai signifikansi lebih kecil dari 0.05 yaitu 0.035 , artinya variabel dewan pengawas syariah berpengaruh negatif dan signifikan terhadap Kinerja Bank Syariah di Indonesia tahun 20142016. Hal ini menunjukkan bahwa hipotesis kedua yang menyatakan dewan pengawas syariah berpengaruh terhadap Kinerja Bank Syariah di Indonesia diterima, namun menunjukkan hasil yang negatif.

b) Hasil pengujian pada variabel Intellectual Capital didapatkan nilai $\mathrm{t}$ hitung sebesar 3.729. Nilai signifikansi lebih kecil dari 0.05 yaitu 0.001, artinya variabel Intellectual Capital berpengaruh terhadap Kinerja Bank Syariah di Indonesia tahun 2014-2016. Hal ini menunjukkan bahwa hipotesis ketiga yang menyatakan Intellectual Capital berpengaruh terhadap Kinerja Bank Syariah di Indonesia diterima.

c) Hasil pengujian pada variabel Corporate Social Responsibility didapatkan nilai $\mathrm{t}$ hitung sebesar 0.157 . Nilai signifikansi lebih besar dari 0.05 yaitu 0.877, artinya variabel Corporate Social Responsibility tidak berpengaruh terhadap Kinerja Bank Syariah di Indonesia tahun 2014-2016. Hal ini menunjukkan bahwa hipotesis keempat yang menyatakan Corporate Social Responsibility berpengaruh terhadap Kinerja Bank Syariah di Indonesia ditolak.

\section{Pembahasan Hasil Pengujian Hipotesis}

Pengaruh Dewan Pengawas Syariah, Intellectual Capital, dan Corporate Social Responsibility terhadap kinerja bank syariah di Indonesia

Berdasarkan hasil pengujian statistik, variabel dewan pengawas syariah, intellectual capital, dan corporate social responsibility berpengaruh secara simultan terhadap kinerja bank syariah di Indonesia periode 2014-2016. Dengan demikian hasil penelitian ini menerima hipotesis pertama $\left(\mathrm{H}_{1}\right)$. Hasil ini menunjukkan bahwa penerapan dewan pengawas syariah yang baik, dengan memanfaatkan intellectual capital serta mengungkapkan corporate social responsibility mampu mempengaruhi nilai ROA sebagai proksi kinerja bank syariah. Walaupun 
demikian, berdasarkan pengujian koefisien determinasi $\left(\mathrm{R}^{2}\right)$ diperoleh nilai sebesar 0.438 . Hal ini berarti bahwa $43.8 \%$ variabel dependen yaitu kinerja bank syariah dapat dijelaskan oleh variabel independen, sedangkan $56.2 \%$ sisanya dipengaruhi faktor-faktor lain yang tidak dimasukkan dalam penelitian ini.

\section{Pengaruh Dewan Pengawas Syariah terhadap kinerja bank syariah di Indonesia}

Berdasarkan hasil pengujian statistik, secara parsial dewan pengawas syariah (DPS) berpengaruh negatif dan signifikan terhadap ROA sebagai proksi kinerja bank syariah di Indonesia periode 2014-2016. Hal ini dapat dilihat dari hasil uji hipotesis dengan nilai $t$ sebesar -2.243 yang berarti berpengaruh negatif, tingkat signifikansi $0.035<0.05$ yang berarti signifikan, kesimpulannya bahwa hasil penelitian ini menerima hipotesis kedua $\left(\mathrm{H}_{2}\right)$ dengan berpengaruh secara negatif. Hasil penelitian yang menunjukkan ke arah negatif yang artinya setiap kenaikan ukuran DPS maka akan menurunkan nilai ROA pada bank syariah.

Hasil penelitian ini berbeda dengan penelitian sebelumnya yang diteliti oleh Musibah dan Wan (2014) yang menyatakan bahwa DPS berpengaruh positif terhadap kinerja keuangan bank syariah. Penelitian yang dilakukan oleh Mollah dan Zaman (2015) juga menyatakan bahwa ukuran DPS berpengaruh positif terhadap kinerja keuangan bank syariah. Namun, hasil penelitian ini mendukung penelitian yang dilakukan oleh Asrori (2014) juga menyatakan bahwa tugas dan tanggungjawab DPS tidak berpengaruh positif kerhadap kinerja bank syariah di Indonesia. Penelitian yang dilakukan oleh Rismayani dan Ulfa (2018) menyatakan bahwa dewan pengawas syariah berpengaruh negatif terhadap kinerja BUS di Indonesia. Hal ini kemungkinan disebabkan karena jumlah DPS semakin banyak maka kemungkinan terjadinya perdebatan yang tidak diperlukan dan penundaan dalam pembuatan keputusan, selain itu DPS didalam sebuah bank mempunyai rangkap jabatan sebagai DPS di bank lain yang mengakibatkan kurang fokusnya kinerja seorang DPS dalam mengawasi sebuah bank, sehingga kinerja DPS dianggap kurang baik. Mengingat dalam peraturan BI No. 11/33/PBI/2009, DPS memiliki tugas dan tanggung jawab memberikan nasehat dan saran kepada Direksi serta mengawasi kegiatan bank agar sesuai dengan prinsip syariah.

\section{Pengaruh Intellectual Capital terhadap kinerja bank syariah di Indonesia}

Berdasarkan hasil pengujian statistik, secara parsial Intellectual Capital berpengaruh positif dan signifikan terhadap ROA sebagai proksi kinerja bank syariah di Indonesia periode 2014-2016. Hal ini dapat dilihat dari hasil uji hipotesis dengan nilai $t$ sebesar 3.729 yang berarti berpengaruh positif, tingkat signifikansi $0.001<0.05$ yang berarti signifikan, kesimpulannya bahwa hasil penelitian ini menerima hipotesis ketiga $\left(\mathrm{H}_{3}\right)$.

Penelitian ini konsisten dengan penelitian yang dilakukan oleh Nizar \& Anwar (2015) menyatakan bahwa Intellectual Capital berpengaruh terhadap kinerja keuangan yang diproksikan dengan ROA pada bank syariah. Penelitian Mayangtari \& Wahidahwati (2016) juga menunjukkan bahwa Intellectual Capital berpengaruh positif dan signifikan terhadap kinerja keuangan ROA. Hasil penelitian inipun juga sesuai dengan teori yang ada sebagaimana Steward dalam Ulum (2013) bahwa intellectual capital merupakan jumlah dari segala sesuatu tentang sumber daya yang ada diperusahaan yang dapat memberikan keunggulan kompetitif dipasar. Jika perusahaan menghasilkan modal intelektual semakin tinggi, maka kinerja perusahaan semakin meningkat, begitu juga sebaliknya, jika perusahaan menghasilkan modal intelektual semakin rendah, maka kinerja perusahaan juga semakin memburuk.

\section{Pengaruh Corporate Social Responsibility terhadap kinerja bank syariah di Indonesia}

Berdasarkan hasil pengujian statistik, secara parsial Corporate Social Responsibility tidak berpengaruh terhadap ROA sebagai proksi kinerja bank syariah di Indonesia periode 2014-2016. Hal ini dapat dilihat dari hasil uji hipotesis dengan nilai $t$ sebesar 0.157 dengan tingkat signifikansi $0.877>0.05$, yang berarti bahwa hasil penelitian ini menolak hipotesis keempat $\left(\mathrm{H}_{4}\right)$.

Hasil penelitian ini berbeda dengan penelitian Shoukat dan Nadeem (2014) yang menyatakan bahwa CSR berpengaruh terhadap kinerja yang diukur dengan ROA pada bank di Pakistan. Berdasarkan teori yang ada juga mengemukakan bahwa CSR dipercaya dapat meningkatkan kinerja keuangan perusahaan, dimana investor akan lebih tertarik berinvestasi pada perusahaan yang melakukan aktivitas CSR. Dengan 
ketertarikan tersebut, pendapatan atau income perusahaan akan semakin meningkat dan kinerja juga meningkat.

Namun, hasil penelitian ini sama dengan hasil penelitian yang dilakukan oleh Arifin \& Wardani (2016) menyatakan bahwa Corporate Social Responsibility tidak berpengaruh terhadap kinerja bank syariah yang diukur dengan ROA. Hal ini kemungkinan terjadi karena dalam laporan tahunan, kualitas pelaksanaan CSR yang diungkapkan masih sulit untuk diukur, sehingga hanya sebatas informasi saja tetapi dampak terhadap masyarakat yang sebenarnya tidak diketahui. Selain itu, kemungkinan terjadi karena informasi yang diungkapkan dalam CSR pada bank syariah tidak banyak dikaitkan dengan aktivitas perolehan laba atas aktiva yang digunakan.

\section{Kesimpulan, Keterbatasan dan Saran Kesimpulan}

Berdasarkan hasil pengujian yang telah dilakukan peneliti, dapat disimpulkan bahwa:

1) Dewan Pengawas Syariah (DPS), Intellectual Capital (IC), dan corporate social responsibility (CSR) berpengaruh secara simultan terhadap kinerja bank syariah di Indonesia periode 20142016. Hal ini dilihat dari nilai $F$ sebesar 5.978 dan Signifikansi sebesar $0.004^{\mathrm{b}}$ lebih kecil dari nilai signifikansi $<0.05$.

2) Dewan Pengawas Syariah (DPS) berpengaruh secara negatif dan signifikan terhadap kinerja bank syariah di Indonesia periode 2014-2016. Hal ini dapat dilihat dari hasil uji hipotesis dengan nilai $t$ sebesar -2.243 yang berarti berpengaruh negatif, tingkat signifikansi $0.035<0.05$ yang berarti signifikan.

3) Intellectual Capital (IC) berpengaruh secara positif dan signifikan terhadap kinerja bank syariah di Indonesia periode 2014-2016. Hal ini dapat dilihat dari hasil uji hipotesis dengan nilai $t$ sebesar 3.729 yang berarti berpengaruh positif, tingkat signifikansi $0.001<0.05$ yang berarti signifikan.

4) Corporate Social Responsibility (CSR) tidak berpengaruh terhadap kinerja bank syariah di Indonesia periode 2014-2016. Hal ini dapat dilihat dari hasil uji hipotesis dengan nilai $\mathrm{t}$ sebesar 0.157 dengan tingkat signifikansi $0.877>0.05$.

\section{Keterbatasan Penelitian}

Sebagaimana penelitian lainnya, penelitian ini juga memiliki beberapa keterbatasan yang dijadikan sebagai bahan pertimbangan untuk penelitian selanjutnya guna meningkatkan hasil dimasa yang akan datang, yaitu:

1) Objek penelitian ini hanya mencakup Bank Syariah saja, tidak melibatkan Lembaga Keuangan Syariah (LKS) yang lain seperti Asuransi Syariah, Pegadaian Syariah, ataupun Unit Usaha Syariah.

2) Hanya menggunakan penelitian yang singkat yaitu tiga tahun penelitian periode 2014-2016.

3) Alat ukur kinerja bank syariah hanya menggunakan pengukuran kinerja yang diproksikan dengan ROA.

4) Penelitian ini dibatasi hanya 3 (tiga) variabel saja, yaitu Dewan Pengawas Syariah, Intellectual Capital (IC), dan corporate social responsibility (CSR).

\section{Saran}

Berdasarkan hasil penelitian, kesimpulan dan keterbatasan yang telah dijelaskan sebelumnya, maka saran dari peneliti adalah sebagai berikut:

\section{Saran Akademis}

1) Bagi peneliti selanjutnya, agar menambah lingkup objek penelitian dengan tidak hanya pada Bank Syariah saja, namun juga menambahkan Lembaga Keuangan Syariah (LKS) lainnya seperti Asuransi Syariah, Pegadaian Syariah, ataupun Unit Usaha Syariah.

2) Bagi peneliti selanjutnya dapat melakukan penelitian dengan rentang waktu yang lebih panjang sehingga bisa tercapai hasil dan kesimpulan yang lebih baik.

3) Bagi peneliti selanjutnya mengukur kinerja keuangan tidak hanya menggunakan pengukuran ROA tetapi menggunakan pengukuran Performance Index lainnya seperti ROA, ROE, Net Profit, dan sebagainya, ataupun menggunakan pengukuran Islamicity Index, sehingga dapat menggambarkan kondisi dari kedua sudut pandang yang berbeda. 


\section{Saran Praktis}

1) Bagi bank syariah sebaiknya mempertahankan dan meningkatkan praktik-praktik Dewan Pengawas Syariah (DPS), Intellectual Capital (IC), dan corporate social responsibility (CSR) yang sudah berjalan karena dapat memberikan dampak yang baik bagi perusahaan.

2) DPS dalam bank syariah diperbolehkan untuk merangkap jabatan pada lembaga keuangan syariah lainnya mengakibatkan kurang fokusnya kinerja seorang DPS dalam mengawasi sebuah bank, sehingga kinerja DPS dianggap kurang baik. Oleh karena itu, bank syariah hendaknya melakukan evaluasi terhadap DPS dengan menambahkan anggota DPS yang memenuhi kriteria yang telah ditetapkan.

a. Bagi bank syariah sebaiknya jumlah kegiatan sosial yang dilakukan untuk lingkungan sekitar dan masyarakat umum lebih ditingkatkan, sehingga bank dapat mendatangkan manfaat yang lebih banyak bagi pihak lain yang membutuhkan

\section{Daftar Pustaka}

Asrori. 2014. Implementasi Islamic Corporate Governance dan Implikasinya terhadap Kinerja Bank Syariah. Jurnal Dinamika Akuntansi, 6(1): 90-102.

Arifin, Johan \& Eke Ayu Wardani. 2016. Islamic Corporate Social Responsibility Disclosure, Reputasi, dan Kinerja Keuangan: Studi pada Bank Syariah di Indonesia. Jurnal Akuntansi \& Auditing, 20(1): 37-46.

Nizar, Achmad Syaiful dan Moch. Khoirul Anwar. 2015. Pengaruh Pembiayaan Jual Beli, Pembiayaan Bagi Hasil dan Intellectual Capital terhadap Kinerja Keuangan Bank Syariah. Jurnal Akuntansi akrual, 6(2): 127-143.

Ali, Zainuddin. 2010. Hukum Perbankan Syariah. Jakarta: Sinar Grafika.

Antonio, Muhammad Syafii, 2011. Bank Syariah: Dari Teori ke Praktek. Jakarta: Gema Insani Press.

Ante, Pulic. 1998. Measuring the Performance of Intellectual Potential in Knowledge Economy (presented in 1998 at the 2nd McMaster World Congress on Measuring and Managing Intellectual Capital). Austrian: Team for Intellectual Potential.
Bank Indonesia. 2009. Peraturan Bank Indonesia Nomor 11/33/PBI/2009 tentang Pelaksanaan Good Corporate Governance bagi Bank Umum Syariah dan Unit Usaha Syariah.

Brigham, Eugene F. dan Joel F. Houston. 2010. Dasar-dasar Manajemen Keuangan. Jakarta: Salemba Empat.

Chen, M.C., Cheng, S.J., Hwang, Y. 2005. An Empirical Investigation of the Relationship between Intellectual Capital and Firms' Market Value and Financial Performance. Journal of Intellectual Capital, 6(2): 159-176.

Data Statistik Perkembangan PerbankanSyariah, dari http://www.ojk.go.id/id/kanal/syariah/data-danstatistik/statistik-perbankan-syariah/default.aspx diakses pada tanggal 12 september 2017.

Dipraja, Ibnu. 2014. Pengaruh Corporate Social Responsibility terhadap Kinerja Keuangan (Studi Empiris pada Perusahaan Manufaktur yang Terdaftar di BEI Periode 2010-2012). Dian Nuswantara University Journal Of Accounting : 117.

Depdiknas. 2008. Kamus Besar Bahasa Indonesia. Gramedia Pustaka Utama.

Djokosantoso, Moeljono. 2005. Good Corporate Culture sebagai Inti dari Good Corporate Governance. Jakarta: PT. Elex Media Komputindo.

Elkington, J. 1998. Cannibals With Forks: The Tripple Bottom Line in 21 $1^{\text {st }}$ Century Business. BC: New Society Publishers. Gabriola Island.

Edvinsson, L. dan M. Malone. 1997. Intellectual Capital: Realizing Your Company's True Value by Finding Its Hidden Brainpower. New York : HarperCollins

Fauziah, Khusnul dan Prabowo Yudho J. 2013. Analisis Pengungkapan Tanggung Jawab Sosial Perbankan Syariah di Indonesia Berdasarkan Islamic Social Reporting. Jurnal Dinamika Akuntansi. 5(1): 12-20

Fahmi, Irham. 2012. Analisis Kinerja Keuangan. Cetakan Kesatu, Bandung: Alfabeta.

Faozan, Akhmad. 2013. Implementasi Good Corporate Governance dan Peran Dewan Pengawas Syariah di Bank Syariah. Jurnal Ekonomi Islam La Riba, 7(1): 1-14.

Ferdyant, Ferly, Ratna Anggraini Zr dan Erika Takidah. 2014. Pengaruh Kualitas Penerapan Good Corporate Governance dan Risiko Pembiayaan terhadap Profitabilitas. Jurnal Dinamika Akuntansi dan Bisnis. 2(1): 134-149

Ghaffar. 2014. Corporate Governance dan Profitability of Islamic Banks Operating in Pakistan. Interdisciplinary Journal of Contemporary Research in Business (IJCRB). 6(6): 320-336. 
Ghozali, Imam, 2013. Aplikasi Analisis Multivariate dengan Program SPSS. Edisi Ketujuh. Semarang: Universitas Diponegoro.

Gustani dan Ai Nur Bayinah. 2014. Model Pelaporan Kinerja Sosial Perbankan Syariah: Implementasi Islamic Social Reporting Index (Indeks ISR) di Indonesia. Jurnal Akuntansi dan Keuangan Islam, 2(1).

H, Kusuma dan Ayumardani A. 2016. The Corporate Governance Efficiency and Islamic Bank Performance : An Indonesian Evidence. Polish Journal of Management Studies. 1(13): 111-120.

Helfert, Erich. A, 1996, Teknik Analisis Keuangan (Petunjuk Praktis Untuk Mengelola dan Mengukur Kinerja Perusahaan), Edisi 8, Jakarta: Erlangga.

Ichmawan, Arly. 2014. Analisis Pengaruh Intellectual Capital Terhadap Kinerja Keuangan Bank Umum Syariah di Indonesia (Studi empiris bank umum syariah yang terdaftar di Bank Indonesia tahun 2010 -2012). Jurnal Publikasi. Semarang: Universitas Diponegoro.

Ikatan Akuntansi Indonesia. 2002. Standar Akuntansi Keuangan. Jakarta: Salemba Empat.

Jazil, Thuba and Syahruddin. 2013. The Performance Measures of Selected Malaysian and Indonesian: Islamic Banks Based on The Maqasid al-Shari'ah Approach. Ijtihad, 7(2): 279-301

Karim, Adiwarman. 2004. Bank Islam, Analisis Fiqih dan Keuangan. Raja Grafindo Persada. Jakarta.

Kholid, Muamar Nur dan Arief Bachtiar. 2015. Good Corporate Governance dan Kinerja Maqasid Syariah Bank Syariah di Indonesia. JAAI, 19(2): 126-136.

Libyanita, Mayangtari dan Wahidahwati (2016). Pengaruh Intellectual Capital terhadap Kinerja Keuangan dengan Competitive Advantage sebagai Variabel Intervening. Jurnal Ilmu dan Riset Akuntansi, 5(6): 1-19.

Malik, M. Shoukat dan Muhammad Nadeem. 2014. Impact of Corporate Social Responsibility on the Financial Performance of Banks in Pakistan. International Letters of Social and Humanistic Sciences. 21: 9-19.

Maradita, Aldira. 2012. Karakteristik Good Corporate Governance pada Bank Syariah dan Bank Konvensional. Yuridika. 12(2).

Mollah, Sabur dan Mahbub Zaman. 2015. Shari'ah Supervision, Corporate Governance and Performance: Conventional vs. Islamic Banks. Journal of Banking and Finance, 58(C): 418-435.

Musibah, Anwar Salem dan Wan Sulaiman Bin Wan Yusoff Alfattani. 2014. The Mediating Effect of Financial Performance on the Relationship between Shariah Supervisory Board Effectiveness, Intellectual Capital and Corporate
Social Responsibility, of Islamic Banks in Gulf Cooperation Council Countries. Asian Social Science, 10(17): 139-164.

Muhamad. 2014. Manajemen Dana Bank Syariah. Cetakan Kesatu. Jakarta : PT. Raja Grafindo Persada.

Muttakin, M.B, dan M.S.Ullah. 2012. Corporate Governance and Bank Performance: Evidence from Bangladesh. Corporate Board: Role, Duties \& Composition, 8 (1): 62-68.

Najib, Haifa dan Rini. 2016. Sharia Compliance Islamic Corporate Governance dan Fraud pada Bank Syariah. Jurnal Akuntansi dan Keuangan Islam, 4(2): 131-146.

Nurhikmah, Febty, Winarsih dan Metta Kusumaningtyas. 2018. Pengaruh Dewan Pengawas Syariah dan Intellectual Capital terhadap Pengungkapan Corporate Social Responsibility dengan Kinerja Keuangan sebagai Variabel Mediasi (Studi Empiris Perbankan Syariah di Indonesia). Journal of Islamic Banking and Finance, 2(2): 174-188.

Putri, Agni A. dan Agus Purwanto. 2013. Pengaruh Intellectual Capital terhadap Kinerja Perusahaan Perbankan yang Terdaftar di Busa Efek Indonesia tahun 2009-2011. Journal of Accounting, 2(3): 1-12.

Paul. 2015. Impact of Corporate Governance on Financial Performance of Microfinance Bank in North Central Nigeria. International Journal of Humanities Social and Education (IJHSSE), 2(1): 153-170.

Pengungkapan OJK tentang Rasio Profitabilitas Bank menurun di 2016, https://www.republika.co.id/berita/ekonomi/keuan gan/17/02/03/okspdy383-ojk-rasio-profitabilitasbank-2016-menurun diakses pada tanggal 18 Oktober 2017.

Prasetya, Dimas Nurdy \& Siti Mutmainah. 2011. Analisis Pengaruh Intellectual Capital Terhadap Islamicity Finansial Performance Index Bank Syariah di Indonesia. Jurnal Bisnis dan Akuntansi, 2(3): 1-28.

Putrianingsih, Dwi Indah dan Arief Yulianto. 2016. Pengaruh Non Performing Loan (Npl) dan Capital Adequacy Ratio (Car) terhadap Profitabilitas. Management Analysis Journal, 5(2): 109-115.

Rahmat, Biki Zulfikri. 2017. Optimalisasi Peran Dewan Pengawas Syariah dalam Pelaksanaan Good Corporate Governance di BPRS Harum Hikmahnugraha. Jurnal Amwaluna, 1(2): 276-296.

Rosiliana, K., G. A. Yuniarta dan N.A.S. Darmawan. 2014. Pengaruh Pengungkapan 
Corporate Social Responsibility terhadap Kinerja Keuangan. E-journal S1 Akuntansi. Universitas Pendidikan Ganesha. 2(1): 1-26.

Shofa, Fierda. 2014. Pengaruh Intelectual Capital Terhadap Kinerja Keuangan Bank Umum Syariah di Indonesia. Skripsi Publikasi. Semarang: Universitas Diponegoro.

Siswanti, Indra. (2016). Implementasi Good Corporate Governance Pada Kinerja Bank Syariah. Jurnal Akuntansi Multiparadigma JAMAL, 7(2): 156-323.

Sekaran, Uma dan Roger Bougie. 2016. Research Methods for Bussiness: a Skill Building Approach. Seventh Edition. United Kingdom: Wiley.

2013. Research Methods for Bussiness: a Skill Building Approach. Sixth Edition. United Kingdom: Wiley.

Sekaran, Uma. 2011. Metodologi Penelitian Untuk Bisnis. Buku Dua. Edisi Keempat. Jakarta: Penerbit Salemba Empat.

Sugiyono. 2013. Metode Penelitian Kuantitatif, Kualitatif, dan $R \& D$. Bandung: CV. Alfabeta.

Sriviana, Eva. 2013. Pengaruh Pengungkapan Corporate Social Responsibility dan Ukuran Perusahaan Terhadap Profitabilitas. Jurnal Ilmu dan Riset Akuntansi, 2 (4): 2-16.

Stewart, T.A. 1997. Intellectual Capital: The new Wealth of Organizations. New York: Doubleday Dell Publishing Group, Inc.

Sudarsono, Heri. 2012. Bank dan Lembaga Keuangan Syariah Deskriptif dan Ilustrasi. Yogyakarta: Ekonosia.

Syam, Daniel dan Taufik Nadja. 2012. Analisis Kualitas Penerapan Good Corporate Governance pada Bank Umum Syariah di Indonesia Serta Pengaruhnya terhadap Tingkat Pengembalian dan Risiko Pembiayaan. Jurnal Reviu Akutansi dan Keuangan, 2(1): 195-206.

Ulum, Ihyaul. 2008. Intellectual Capital Performance Sektor Perbankan di Indonesia. Jurnal Akuntansi dan Keuangan, 10(2).

2009. Analisis Inter-relasi antar Komponen Intellectual Capital dan Kinerja Keuangan Perusahaan. Journal of Intellectual Capital.

2013. Model Pengukuran Kinerja Intellectual Capital dengan IB-VAIC di Perbankan Syariah. Jurnal Inferensi, 7(1): 183-204.

Undang-undang No. 21 tahun 2008 tentang Perbankan Syariah.

www.bi.go.id/id/peraturan/perbankan/Pages/PBI_7120

9.aspx diakses pada tanggal 18 september 2017.

www.ojk.co.id diakses 14 september 2017
Wardani, Eka Ayu. 2015. Pengaruh Islamic Corporate Social Responsibility Disclosure Terhadap Reputasi Perusahaan dan Kinerja Keuangan Perusahaan. Jurnal Publikasi. Jakarta: Universitas Islam Indonesia.

Wardayati, Siti Maria. 2011. Implikasi Shariah Governance terhadap Reputasi dan Kepercayaan Bank Syariah. Jurnal Walisongo, 19(1):1-24. www.syariahmandiri.co.id. Diakses 15 Oktober 2017. www.bankmuamalat.co.id. Diakses 15 Oktober 2017. www.megasyariah.co.id. Diakses 15 Oktober 2017. www.brisyariah.co.id. Diakses 15 Oktober 2017. www.syariahbukopin.co.id. Diakses 15 Oktober 2017. www.panindubaisyariah.co.id. Diakses 21 Oktober 2017.

www.bankvictoriasyariah.co.id. Diakses 21 Oktober 2017.

www.bcasyariah.co.id. Diakses 21 Oktober 2017. www.bnisyariah.co.id. Diakses 21 Oktober 2017. www.maybanksyariah.co.id. Diakses 22 Oktober 2017.

www.bjbsyariah.co.id. Diakses 22 Oktober 2017.

Yuliani, Rahma Dwi. 2016. Corporate Governance dan Pengungkapan Islamic Social Reporting pada Perbankan Syariah di Indonesia dan Malaysia. Jurnal Publikasi. Yogyakarta: Universitas Muhammadiyah 